\title{
Työpanos maatalousyrityksissä
}

\author{
Alina Sinisalo \\ MTT Taloustutkimus, Latokartanonkaari 9,00790 Helsinki, alina.sinisalo@mtt.fi
}

\section{Tiivistelmä}

Maatalous on edelleen varsin työvoimavaltaista, vaikka maatalous on koneellistunut vuosien aikana. Maatiloilla työt tehdään pääosin edelleenkin viljelijäperheen voimin, vaikka etenkin puutarhatiloilla ja avomaatuotannossa käytetään sesonkiaikana runsaasti ulkopuolista työvoimaa. Koska viljelijäperhe yleensä asuu maatilalla, voi työn ja vapaa-ajan erottaminen olla ongelmallista. Lisäksi tilan vanhempi sukupolvi ja naapurit voivat osallistua tilan töihin. Myös vuodenaikojen kiertokulusta aiheutuva kausiluonteisuus ja vaihtelevat sääolosuhteet vaikuttavat työmenekkiin. Maatalousyrittäjien oman työnmäärän määrittäminen on monilta osin ongelmallista. Maatalousyrittäjien työtunnit arvottamalla saatava palkkavaatimus-kustannus muodostaa kuitenkin merkittävän osan yritysten kokonaiskustannuksista. Työnmenekin määrän ja palkkavaatimuskustannuksen on todettu olevan eräs tärkeimmistä maatalousyrityksen kannattavuuteen vaikuttavista tekijöistä. Työvoimatietoja käytetään paitsi erilaisten tunnuslukujen laskennassa, myös neuvontapalveluissa, tutkimuksessa, poliittisten päätösten vaikuttavuuden seurannassa ja lainsäädännön valmistelussa. Työaikatietojen mahdollisimman tarkka kerääminen onkin tärkeää.

Tutkimuksessa tarkastellaan viljelijäperheen ja palkkaväen työpanoksen kehittymistä maa- ja puutarhataloudessa viime vuosina. Aineistoina käytetään eri tilastoja ja MTT:n kannattavuuskirjanpitotilatietoja. Tarkastelut ja vertailut tehdään alueittain, tilakokoluokittain ja tuotantosuunnittain. Ryhmien välisiä eroja testataan pareittain ja merkitsevimmät erot esitellään yksityiskohtaisemmin.

Keskimääräinen kokonaistyöpanos on pienentynyt eri suuralueilla vuosina 1998-2009. Suurin ero on Etelä- ja Pohjois-Suomen välillä $(\mathrm{p}<0,001)$. Pohjoisessa työpanos on pienentynyt vähiten $(-10 \%)$. Suhteellisesti eniten työpanos on vähentynyt pienillä tiloilla ja vähiten suurilla tiloilla $(p<0,001)$. Keskimääräinen kokonaistyöpanos on vähentynyt suhteellisesti eniten muuta kasvinviljelyä harjoittavilla tiloilla $(-42 \%)$. Toiseksi eniten työpanos on vähentynyt viljanviljelyssä $(-21 \%)$. Lypsykarjatiloilla työpanoksen määrä on pysynyt lähes muuttumattomana.

Asiasanat: työpanos, viljelijäperhe, palkattuväki, suuralue, tilakoko, tuotantosuunta 


\section{Johdanto}

Maatalous on edelleen varsin työvoimavaltaista, vaikka maatalous onkin koneellistunut paljon vuosien aikana. Maatiloilla työt tehdään pääosin viljelijäperheen voimin, mutta aiemmin palkatun työvoiman osuus on ollut nykyistä selvästi suurempi. Nykyisin etenkin puutarhatiloilla ja avomaatuotannossa käytetään sesonkiaikana ulkopuolista työvoimaa. Koska viljelijäperhe yleensä asuu maatilalla, voi työn ja vapaa-ajan erottaminen olla ongelmallista. Lisäksi tilan vanhempi sukupolvi ja naapurit voivat osallistua tilan töihin. Maatalous perustuu yrittäjyyteen, luonnolliseen vuodenaikojen kiertokulusta aiheutuvaan kausiluonteisuuteen ja lisäksi vaihtelevat sääolosuhteet vaikuttavat töiden suorittamiseen tarvittavaan aikaan. Maatalouden työnmenekin määrittäminen on siten ongelmallista.

Työnmenekin määrä on todettu erääksi tärkeimmiksi yrityksen kannattavuuteen vaikuttavista tekijöistä (Torvela, 1987). Työn tuottavuutta voidaan mitata työpanosyksikköä kohden aikaansaadulla tuotannon määrällä. Suomen maatalouden työn tuottavuus on parantunut 1990-luvun alusta lähtien noin 5\% vuodessa ja vuonna 2009 työpanosta kohden aikaansaatu tuotannon määrä oli 2,2 kertaa suurempi kuin vuonna 1992. Samana aikana kokonaistyöpanos on pienentynyt 56\%. Yrittäjäperheen työpanos maatilaa kohden on laskenut keskimäärin 3\% vuodesta 2000 vuoteen 2009 välisellä jaksolla (Niemi ja Ahlstedt, 2011). Maataloudessa oman työn kustannus eli palkkavaatimus määritetään työkirjanpitoon kirjattujen yrittäjäperheen työtuntien perusteella, ja saadaan kertomalla työtunnit ennalta asetetulla tuntipalkkavaatimuksella. Maataloudessa työ muodostaa merkittävän osan kustannuksista. Vuonna 2010 maa- ja puutarhatalouden tuotantokustannuksista yrittäjäperheen palkkavaatimuskustannusten osuus oli noin 20\% (Niemi ja Ahlstedt, 2011).

Juuri kustannuksien takia työtietojen keruu on tarpeellista. Työvoimatietoja käytetään erilaisten tunnuslukujen laskennassa, ja niiden avulla voidaan tarkastella työvoiman merkitystä elinkeinossa. Tuotantoa laajennettaessa työaikatietojen saatavuus on tärkeää riittävien resurssien varaamista varten. Maatalousyritysten sisäisen laskennan lisäksi työaikatietoja käytetään neuvontapalveluissa, tutkimuksessa, poliittisten päätösten vaikuttavuuden seurannassa ja lainsäädännön valmistelussa.

Tässä tutkimuksessa tarkastellaan viljelijäperheen ja palkkaväen työpanoksen kehittymistä maaja puutarhataloudessa viime vuosina. Tarkastelut ja vertailut tehdään alueittain, tilakokoluokittain ja tuotantosuunnittain. Ryhmien välisiä eroja testataan pareittain ja merkitsevimmät erot esitellään yksityiskohtaisemmin.

\section{Aineisto ja menetelmät}

Aineistona käytettiin MTT Taloustohtorin Maa- ja puutarhatalous -palvelimen tuottamia painotettuja työpanoskeskiarvolukuja aikaväliltä 1998-2009. Taloustohtorin aineisto kattaa noin 40000 tilaa. Lisäksi tarkempaa tarkastelua varten (ryhmien väliset erot) tilakohtaisena aineistona käytettiin MTT:n kirjanpitoaineistoja vuosilta 1998 ja 2009. Aineistoissa oli yli 700 kirjanpitotilaa molempana tarkasteluvuotena. Kirjanpitoaineistoista tarkasteltiin vain tiloja, joiden tuotantosuunta oli viljanviljely, muu kasvintuotanto, lypsykarjatalous, muu nautakarjatalous tai sikatalous. Puutarhatuotanto jätettiin pois tarkastelusta, koska työaikatiedot ja työntekijöiden määrä tiloilla vaihtelevat paljon vuosittain ja tuotanto riippuu paljon sääolosuhteista. Lisäksi puutarhatuotantoon luetaan mukaan sekä avomaatilat ja kasvihuonetilat, joten analyysia ajatellen ryhmä on varsin heterogeeninen. Puutarhatyöt vaativat tietyn järjestyksen ja ajankohdan, joihin yrittäjä ei voi vaikuttaa. Puutarhayrityksissä käytetään paljon palkattua työvoimaa, josta merkittävä osa on ulkomaalaista. Siipikarja- ja hevostalous sekä lammas- ja vuohitalous jätettiin pois tarkasteluista niiden pienen havaintomäärän takia.

Tutkimuksessa tarkasteltiin viljelijäperheen ja palkatun väen työpanosta maa- ja puutarhataloudessa vuosina 1998-2009. Kokonaistyöpanos sisältää maatalouden ja puutarhatalouden työpanoksen. Maataloustyöpanokset jaotellaan lisäksi kasvinviljely- ja kotieläintöihin sekä muihin maataloustöihin. Puutarhatyöpanos jaotellaan tuotantotöihin, markkinointiin ja muihin puutarhatöihin. Puutarhatyöpanosta ei tarkasteltu tässä tutkimuksessa kuin vain kokonaistyöpanoksen yhteydessä. Tarkastelut tehtiin alueittain, tilakokoluokittain ja tuotantosuunnittain. Viljelijäperheen ja palkatun väen keskimääräistä kokonaistyöpanosta, sen kehitystä ja muutoksia kuvattiin vuosien varrella. Tarkemmin tarkasteltiin viljelijäperheen maataloustyöpanosta. Eri ryhmien välisiä eroja testattiin pareittain ja merkitsevimmät erot kuvattiin tarkemmin. Koska parametristen testien oletukset eivät täyttyneet (normaalijakautuneisuus, varianssien yhtäsuuruus), avuksi otettiin ei-paramertrinen testi (Kruskalin-Wallisin testi). 


\section{Tulokset ja tulosten tarkastelu \\ Aluetarkastelut}

Aluetarkastelut tehtiin suuralueittain. Suomi jaettiin Pohjois-, Itä-, Länsi- ja Etelä-Suomeen. Keskimääräinen kokonaistyöpanos on laskenut eri alueilla. Suhteellisesti eniten työpanos on laskenut LänsiSuomessa (22\%), toiseksi eniten Etelä-Suomessa (19\%). Pohjois-Suomessa työpanos on pienentynyt vähiten (10\%). Vuodesta 1995 lähtien vuoteen 2010 mennessä suhteellisesti eniten tilamäärä on pienentynyt Itä-Suomessa ja vähiten Pohjois-Suomessa. Etelä- ja Länsi-Suomessa muutos on ollut hitaampaa kuin Itä-Suomessa (Niemi ja Ahlstedt, 2011).

Itä- ja Pohjois-Suomessa viljelijäperheen keskimääräinen työpanos on suurin (kuva 1). Vuonna 1998 Pohjois-Suomessa viljelijäperhe teki keskimäärin 3800 h/tila, kun Etelä-Suomessa viljelijäperhe teki $2750 \mathrm{~h} /$ tila. Viljelijäperheen työpanos on ollut melko tasaisesti laskussa jokaisella suuralueella vuosien varrella. Vuonna 2009 Pohjois-Suomessa viljelijäperhe teki enää keskimäärin 2980 h/tila ja Etelä-Suomessa 1970 h/tila.

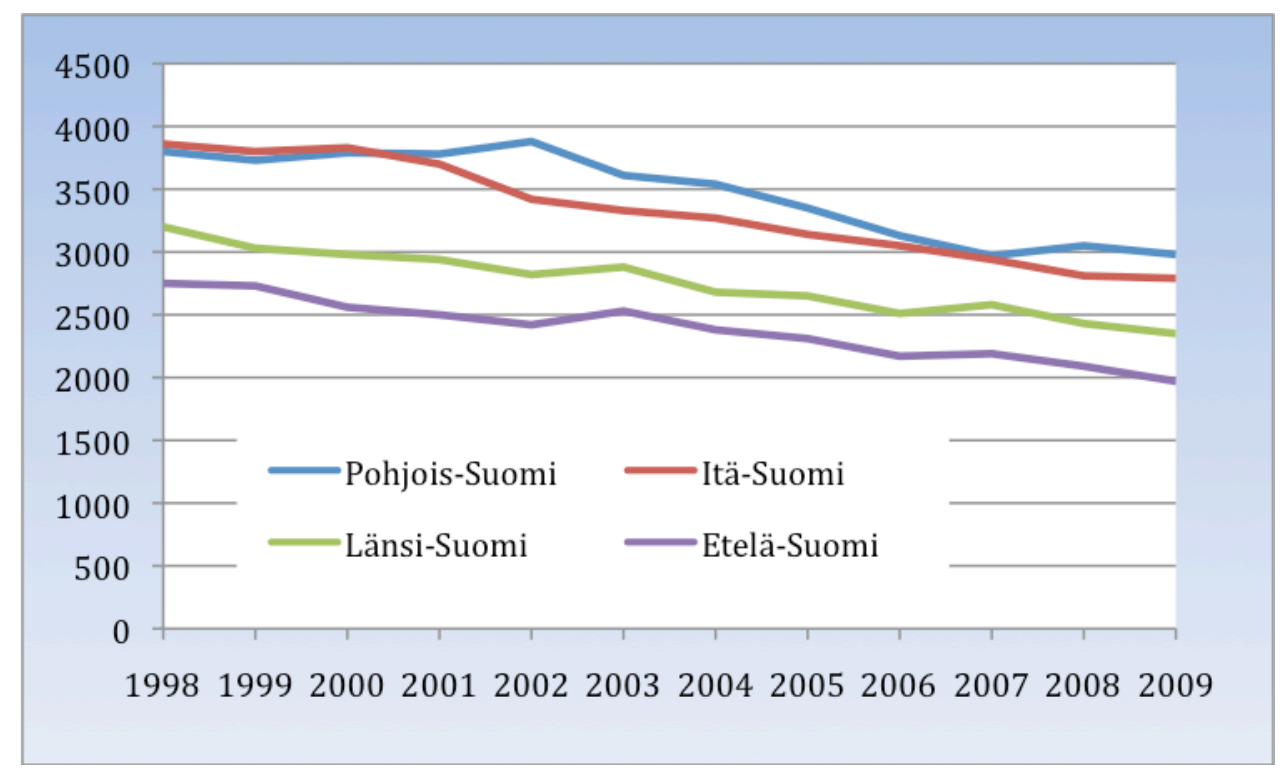

Kuva 1. Viljelijäperheen keskimääräinen kokonaistyöpanos maa- ja puutarhataloudessa vuosina 1998-2009 alueittain (MTT Taloustohtori, Maa- ja puutarhatalous).

Palkatun työvoiman kokonaistyöpanoksessa ei ole havaittavissa vastaavaa selkeää suhdannetta kuin viljelijäperheen keskimääräisen kokonaistyöpanoksen kehityksessä (kuva 2). Palkatun väen käytössä on suuria vuotuisia vaihteluja, etenkin Itä-Suomessa. 


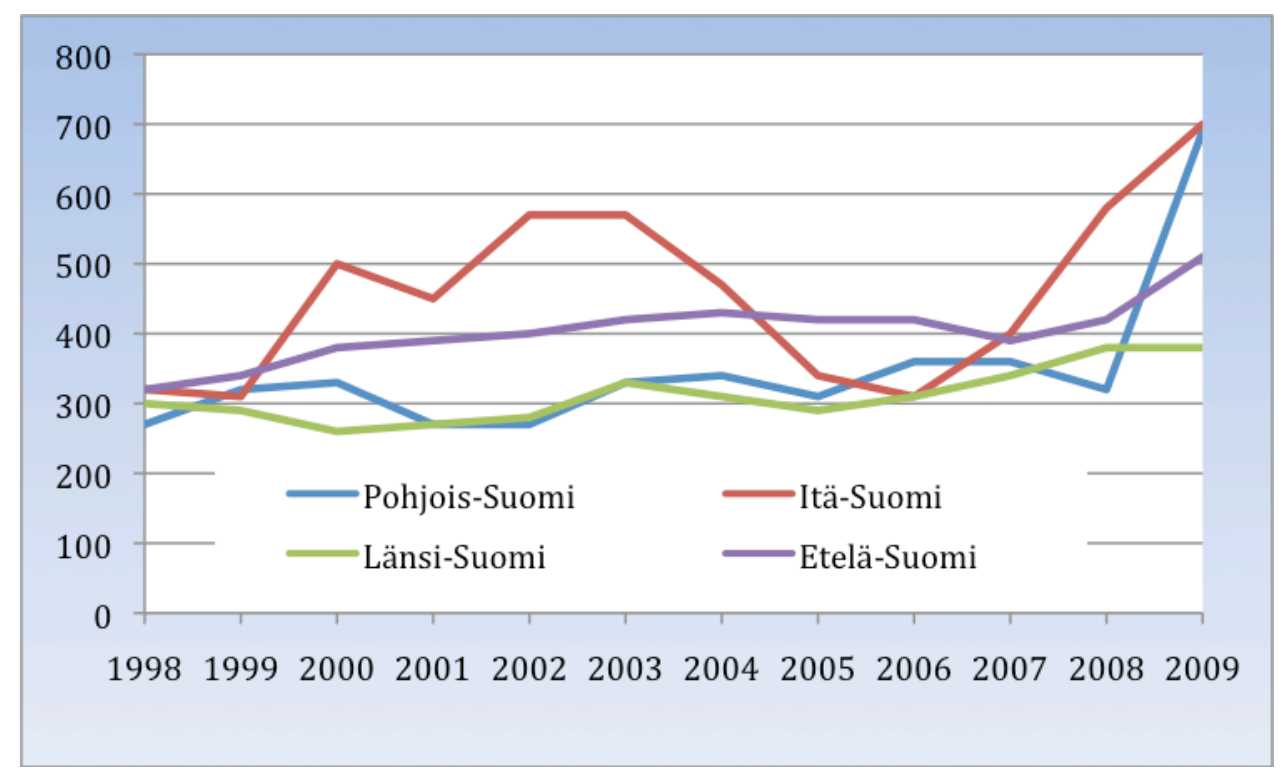

Kuva 2. Palkkaväen keskimääräinen kokonaistyöpanos maa- ja puutarhataloudessa vuosina 1998-2009 alueittain (MTT Taloustohtori, Maa- ja puutarhatalous).

Vuosien 1998 ja 2009 eri suuralueiden viljelijäperheen maataloustyöpanoskeskiarvot testattiin. Erot eri suuralueiden välillä olivat tilastollisesti erittäin merkitseviä ( $<<0,001$, Kruskalin-Wallisin testi) ja suurin ero oli Etelä- ja Pohjois-Suomen välillä ( $<<0,001$, parivertailut). Pohjois-Suomessa eniten työaikaa käytettiin kotieläintöihin ja suhteellisesti enemmän kuin Etelä-Suomessa. Kotieläintöiden määrä Pohjois-Suomessa on vähentynyt, mutta kasvinviljelytöiden ja muiden töiden määrä on pysynyt lähes samana (kuva 3). Etelä-Suomessa sen sijaan viljelijäperheen maataloustyöpanos on laskenut kaikissa ajankäyttö-ryhmissä. Vuosien varrella kasvinviljely- ja kotieläintöiden määrä on lähestynyt toisiaan (kuva 4). Itä- ja Pohjois-Suomessa välimatkat kaupunkeihin ovat muuta maata suuremmat, mikä haittaa maatilan ulkopuolista työssäkäyntiä. Etelässä ja lännessä kaupunkienläheisellä maaseudulla tai ydinmaaseudulla mahdollisuudet ulkopuoliseen työntekoon ovat paremmat (Niemi ja Ahlstedt, 2011). Tilan ulkopuoliseen työskentelyyn vaikuttaa myös tuotantosuunta. Vähiten ulkopuolisessa työssä käydään kotieläintiloilta. Lypsykarjatilat työllistävät yleensä viljelijän ja hänen puolisonsa, sillä vain 17\% lypsykarjatilojen puolisoista käy päätoimisesti ulkopuolisissa töissä (Tike, 2006).

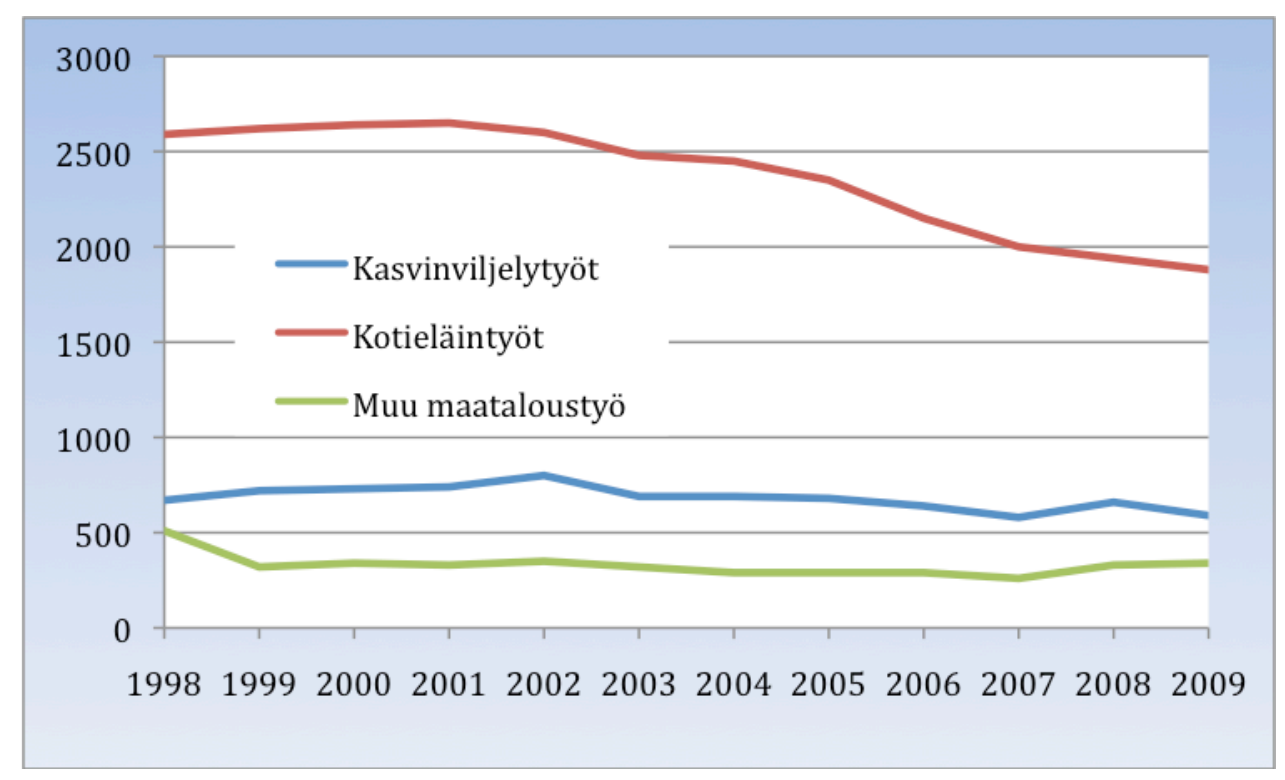

Kuva 3. Viljelijäperheen maataloustyöpanos maa- ja puutarhataloudessa Pohjois-Suomen suuralueella vuosina 1998-2009 (MTT Taloustohtori, Maa- ja puutarhatalous). 


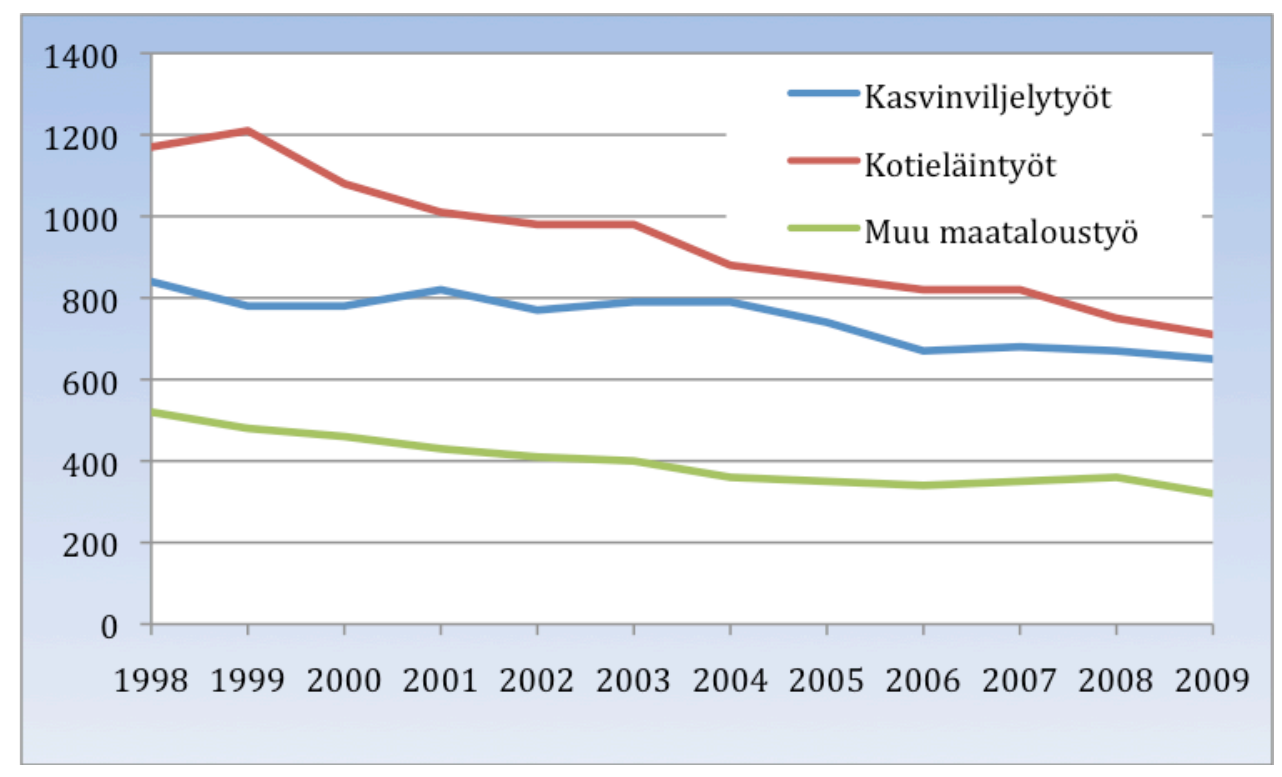

Kuva 4. Viljelijäperheen maataloustyöpanos maa- ja puutarhataloudessa Etelä-Suomen suuralueella vuosina 1998-2009 (MTT Taloustohtori, Maa- ja puutarhatalous).

\section{Tilakoko}

Vuosina 2000-2010 tilojen määrä on vähentynyt 21\%; 79783 tilasta on lopettanut toimintansa yhdentoista vuoden aikana 17016 tilaa (Tike, Maatilojen rakenne). Tilojen keskikoko on kasvanut pienempien tilojen määrän vähentyessä ja suurien tilojen lukumäärän lisääntyessä (Niemi ja Ahlstedt, 2011).

Tilojen kokoluokat määriteltiin tilan taloudellisen koon mukaan. Vakioitu kate on taloudellisilta kooltaan pienillä tiloilla $9600-14400 €$, melko pienillä 14 400-24 000 €, keskikokoisilla 24000 $38400 €$, melko suurilla 38 400-57 $600 €$, suurilla 57 600-115 $200 €$, hyvin suurilla 115200 $172800 €$ ja erittäin suurilla yli $172800 €$.

Keskimääräinen kokonaistyöpanos on laskenut eri tilakokoluokissa vuodesta 1998 vuoteen 2009. Suhteellisesti eniten työpanos on pienentynyt melko pienillä $(-52 \%)$ ja pienillä $(-48 \%)$ tiloilla. Vähiten työpanos on pienentynyt hyvin suurilla $(-10 \%)$ ja suurilla $(-16 \%)$ tiloilla. Sen sijaan viljelijäperheen keskimääräinen kokonaistyöpanos erittäin suurilla tiloilla on kasvanut yli neljänneksellä. Viljelijäperheen työpanos erittäin ja hyvin suurilla tiloilla on kuitenkin vaihdellut paljon. Muissa kokoluokissa viljelijäperheen työpanos on tasaisesti pienentynyt (kuva 5).

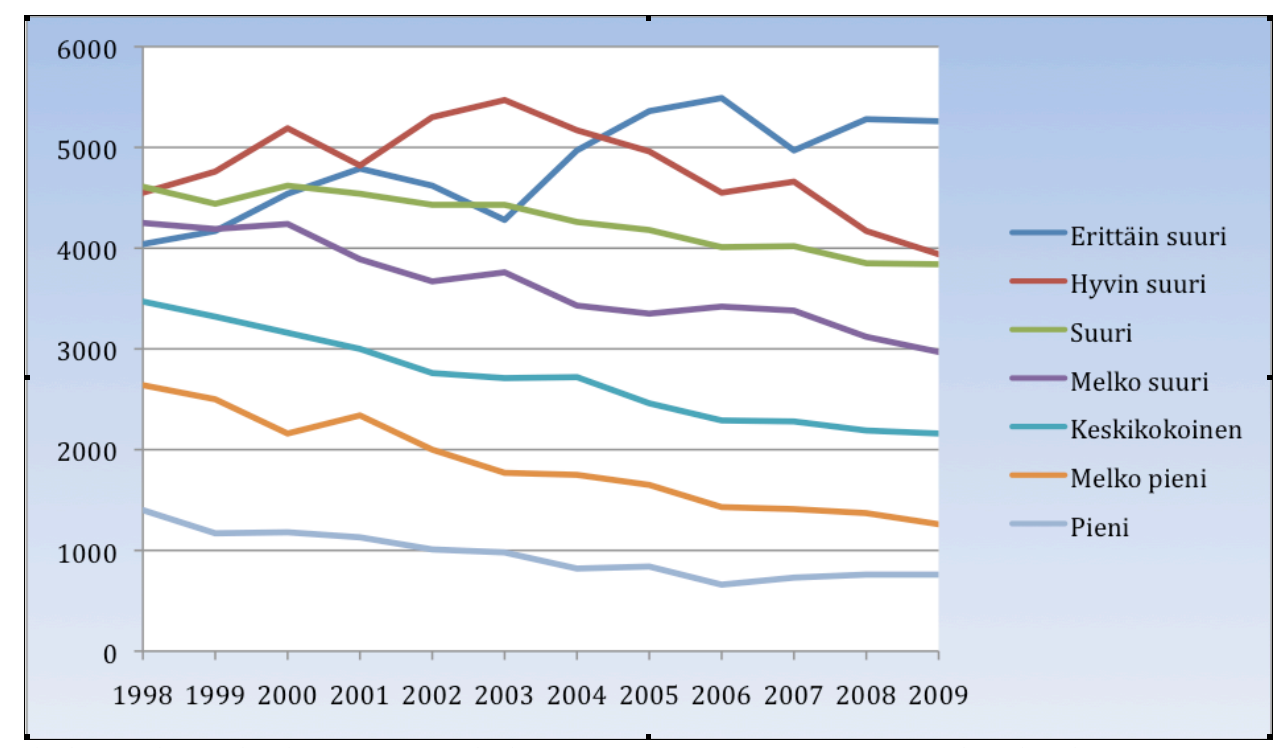

Kuva 5. Viljelijäperheen keskimääräinen kokonaistyöpanos maa- ja puutarhataloudessa vuosina 1998-2009 tilakokoluokittain (MTT Taloustohtori, Maa- ja puutarhatalous). 
Vuodesta 1998 vuoteen 2009 mennessä palkkaväen työpanos erittäin suurilla tiloilla on enemmän kuin puolittunut. Erittäin suurilla tiloilla kokonaistyöpanoksen kasvu selittyy sillä, että viljelijäperheen osuus töistä on selvästi kasvanut (30\% osuus vuonna 1998 ja 55\% osuus vuonna 2009), mutta palkatun työvoiman osuus on pienentynyt. Hyvin suurilla sekä keskikokoisilla ja niitä pienemmillä tiloilla palkkaväen työpanoksen osuus on pysynyt vuodesta 1998 vuoteen 2009 melko samana.

Vuosien 1998 ja 2009 eri kokoluokkien viljelijäperheen maataloustyöpanoskeskiarvot testattiin. Erot luokkien välillä olivat tilastollisesti erittäin merkitseviä ( $<<0,001$, Kruskalin-Wallisin testi) ja suurin ero oli pienten ja erittäin suurten tilojen välillä ( $<<0,05$, parivertailut). Erittäin suurilla tiloilla suurin osa $(60 \%)$ viljelijäperheen maatalouden työpanoksesta käytettiin kotieläintöihin vuonna 1998 ja työpanos vuosien varrella on vain kasvanut (64\% vuonna 2009). Pienillä tiloilla viljelijäperheen maataloustyöpanos kotieläintöissä on vähentynyt, mutta kasvinviljelytöissä ja muissa maataloustöissä työpanos on pysynyt lähes samana. Pienillä tiloilla kasvinviljelytöiden osuus on selvästi suurin.

Tilakoon mukaan tarkasteltaessa päähuomio on syytä kiinnittää erittäin suurten tilojen joukkoon, sillä sen merkitys kasvaa jatkuvasti, ja toisaalta siinä joukossa tapahtuu eniten muutoksia. Lisäksi näyttää myös siltä, että keskimäärin erittäin suurten tilojen kyky työllistää ulkopuolisia on heikentymässä.

\section{Tuotantosuunta}

Lypsykarja-, sika-, siipikarjatilojen ja muuta nautakarjataloutta harjoittavien tilojen määrä on noin puolittunut kymmenessä vuodessa. Muun kasvintuotannon tilojen määrä sen sijaan on lisääntynyt. Viljanviljelytilojen määrä on pysynyt lähes samana (Tike, Maatilojen rakenne).

Keskimääräinen kokonaistyöpanos on vähentynyt suhteellisesti eniten muuta kasvinviljelyä harjoittavilla tiloilla (-42\%). Toiseksi eniten työpanos on vähentynyt viljanviljelyssä (-21\%). Muuta nautakarjataloutta harjoittavilla tiloilla työpanos on vähentynyt $18 \%$ ja sekamuotoisilla $15 \%$. Lypsykarjatiloilla työpanosten määrä on pysynyt lähes samana. Puutarhatuotannossa töiden kokonaistyöpanos on lisääntynyt (27\%).

Viljelijäperheen keskimääräinen kokonaistyöpanos tiloilla on laskenut. Eniten aikaa käytetään lypsykarjatiloilla. Puutarhatuotannossa keskimääräisten työtuntien vaihtelu on suurta eri vuosien välillä. Palkkaväen kokonaistyöpanos keskimäärin tiloilla on lisääntynyt paitsi kasvinviljelyssä. Palkkaväki tekee eniten työtunteja puutarhatuotannossa (yli $3000 \mathrm{~h} /$ tila). Toiseksi eniten työtä tehdään sikatiloilla (noin $500 \mathrm{~h} /$ tila). Viljanviljelytiloilla palkkaväen työpanos on pysynyt lähes samana, muissa tuotantosuunnissa vuotuisvaihtelu on suurta.

Vuosien 1998 ja 2009 eri tuotantosuuntien viljelijäperheen maataloustyöpanoskeskiarvot testattiin. Aineistossa olivat mukana viljanviljely, muu kasvintuotanto, lypsykarjatalous, muu nautakarjatalous ja sikatalous. Erot tuotantosuuntien välillä olivat tilastollisesti erittäin merkitseviä $(p<0,001$, Kruskalin-Wallisin testi). Suurin ero oli viljanviljely- ja lypsykarjatilojen välillä ( $p<0,001$, parivertailut). Viljanviljelytiloilla suurin osa viljelijäperheen maatalouden työpanoksesta käytetään kasvinviljelytöihin (63\% vuonna 2009). Erikoista viljanviljelytiloilla on se, että muiden maataloustöiden työpanos on vuodesta 1998 vuoteen 2009 vähentynyt, mutta kotieläintyöt ovat pysyneet vuosien varrella lähes muuttumattomina. Lypsykarjatiloilla yli $70 \%$ viljelijäperheen maatalouden työpanoksesta käytetään kotieläintöihin. Kasvinviljelytöiden osuus on pysynyt 15\%:ssa. Kotieläintiloilla viljelijäperheen työpanos on selvästi suurempi kuin kasvintuotantotiloilla. Esimerkiksi lypsykarjatiloilla työpanos on yli kolminkertainen verrattuna viljatiloihin, ja ero näyttää olevan kasvussa.

\section{Johtopäätökset}

Maatilojen kokonaistyöpanos voidaan jakaa kahteen ryhmään, palkattuun ja palkattomaan työvoimaan. Palkattomalla työpanoksella tarkoitetaan viljelijäperhettä. Palkatun työvoiman työpanos voidaan selvittää kirjanpitotietojen avulla. Viljelijäperheen työpanoksen selvittäminen on hankalampaa, työpanostiedot perustuvat viljelijöiden itse täyttämiin tuntikirjoihin. Sopivalla tilavalinnalla, riittävällä havaintomäärällä ja tuloksia painottamalla voidaan työpanostiedoista tehdä koko Suomea koskevia yleisarvioita. Työpanosten kehitystä voidaan tarkastella alueellisesti, tilakoon ja tuotantosuuntien mukaan. Tarkastelujen avulla voidaan saada tietoja maatalouden rakennekehityksestä, sillä työpanostiedot vaikuttavat useisiin taloudellisiin tunnuslukuihin. 
Maatilojen työpanos (h/tila) on ollut laskussa jo pitkään. Viljelijäperheen työpanos on vähentynyt tasaisesti vuosien mittaan, mutta palkkaväen työpanos ei ole kehittynyt vastaavalla tavalla, vaan vuosien välillä on ollut selvää vaihtelua. Kehitys on ollut erilaista eri alueilla, kokoluokissa ja tuotantosuunnissa.

\section{Kirjallisuus}

MTT Taloustohtori. www.mtt.fi/taloustohtori

Niemi, J. \& Ahlstedt, J. (toim.). 2011. Suomen maatalous ja maaseutuelinkeinot 2011. Maa- ja elintarviketalouden tutkimuskeskus. Taloustutkimus. Julkaisuja $111.96 \mathrm{~s}$.

SVT. Tike, Maatilojen rakenne.

Tike. 2006. Maataloustilastotiedote 3/2006. 22 s.

Torvela, M. 1987. Johdanto. s.5-7. Teoksessa: Maatalouden kannattavuustutkimus 75 vuotta. 1987. Maatalouden taloudellisen tutkimuslaitoksen julkaisuja nro $53.123 \mathrm{~s}$. 